\title{
Historical Period Stone Anchors from Mombasa, Kenya: Evidence of Overseas Maritime Trade Contacts with Asia and Middle East
}

\author{
Caesar Bita ${ }^{1, *}$ \\ ${ }^{1}$ National Museums of Kenya, Department of Coastal Archaeology, Fort Jesus World Heritage Site
}

Corresponding author. Tel: +254422220058

Received 21 October 2015

E-mail: mcbita@museums.or.ke

Accepted 30 December 2015

\begin{abstract}
One of the characteristics of the East African Coast has been its accessibility. The sea has been a means of contact with the outside world. Over the last 2000 years, there has been an interpenetration of cultures to this region through trade consequently assimilating this coast into the international economic system. Accessibility from the land has made the East African coast historically an integral part of Africa. This allowed movement of goods from inland to the coast and onward to international markets. This coast has a trade advantage because the monsoon winds and oceanic currents are reliable and permit rapid, seasonal navigation, both along the coast of eastern Africa and across the Indian Ocean to western and southern Asia. A number of scholars have discussed how the monsoon winds and currents facilitated communication between various parts of the Western Indian Ocean (WIO) seaboard and the Red sea, the Persian Gulf, and southeastern Asia. These winds caused long distance seasonal sailing along the East African coast and beyond to the rest of the ancient world. The islands of Comoros and Madagascar were also part of the Western Indian Ocean seaboard cultural and trade networks from very early times even before the BC/AD changeover. One of the major ancient coastal cities that played a role in this transoceanic trade is Mombasa in the Kenya coast. This paper explores these ancient trade contacts which have been proven by historical period stone anchors discovered in Mombasa, Kenya..
\end{abstract}

Keywords: Swahili Coast; East Africa; Mombasa, Stone anchor

\section{Introduction}

\section{The Western Indian Ocean}

The Western Indian Ocean region, commonly referred as the Swahili coast, stretches over 3000 $\mathrm{km}$ from Somalia in the north through Kenya and Tanzania to Mozambique in the South. It also includes island states of Comoro, Seychelles, Madagascar, Reunion and Mauritius. The characteristics of the coastal areas of the mainland countries and Madagascar are similar: alternating beaches, rocky outcrops, coral reefs, large estuarine areas, wetlands, lagoons and inter-tidal flats. The coastline consists of several parts such as the ocean, reefs, lagoons and beaches; rivers and creeks and the low-lying coastal plains (Ase, 1981; 1987; Frazier, 1993; Richmond, 1997). The Indian Ocean has permitted a close network of sailing routes between the lands that surround it. All the lands are linked by their reliance on each other: producing goods needed by others. Sailing between these lands and the settlements has been and is still based on regular and predictable monsoon winds between Indian subcontinent and Africa. That the coastal region has physical and historical trade connectivity with Indian Ocean makes it an important area. Mombasa

\section{Location}

Mombasa is a small coralline island located in the central part of the northern Swahili coast in the coast Kenya Coast at $4^{\circ} 4 \mathrm{~S}$ and $39^{\circ} 43 \mathrm{E}$ (Figure 1). It runs slightly $5 \mathrm{~km}$ long north-south and about $4 \mathrm{~km}$ east-west, with an area of about $14.5 \mathrm{~km} 2$. The town of Mombasa itself is located on the south east end of Mombasa Island. On its south end is the Fort Jesus Monument, and on its eastern shores is the Tudor channel (Figure 2; Map 1). Being a coastal town, Mombasa is characterized by a flat topography. Though centred on Mombasa Island, it also extends to 
the mainland. The island is separated from the mainland by two creeks, Port Reitz in the south and Tudor Creek in the north. Its sheltered deep water anchorage made it an important trading centre in the Swahili coast for many centuries and why the Portuguese chose Mombasa and made it their base.

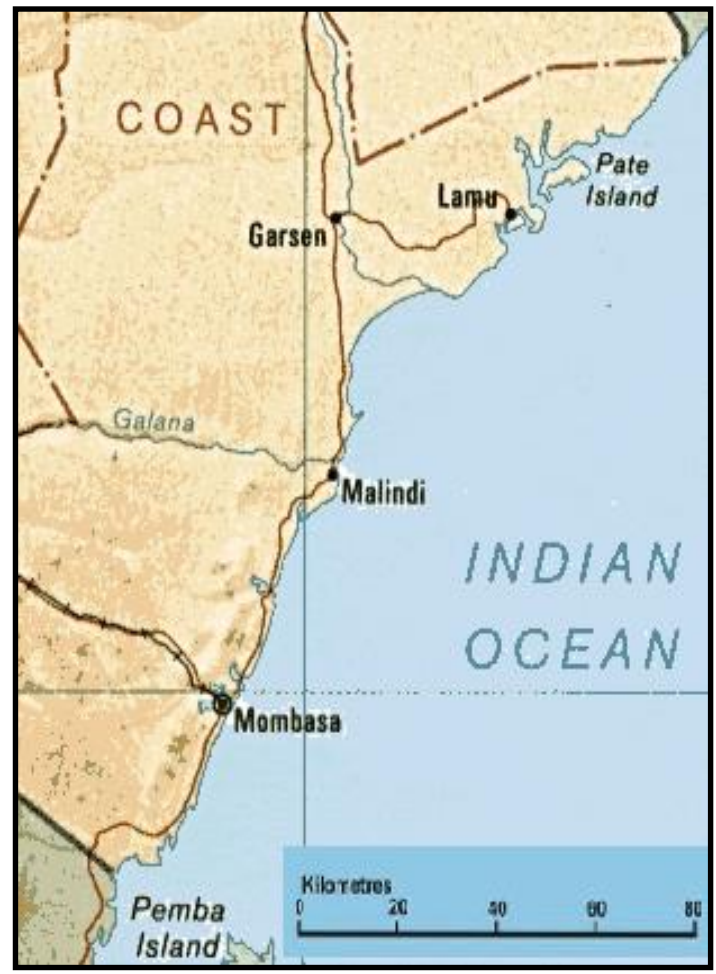

Fig 1. Map of the Kenya Coast showing Mombasa and other major ancient trade centers.

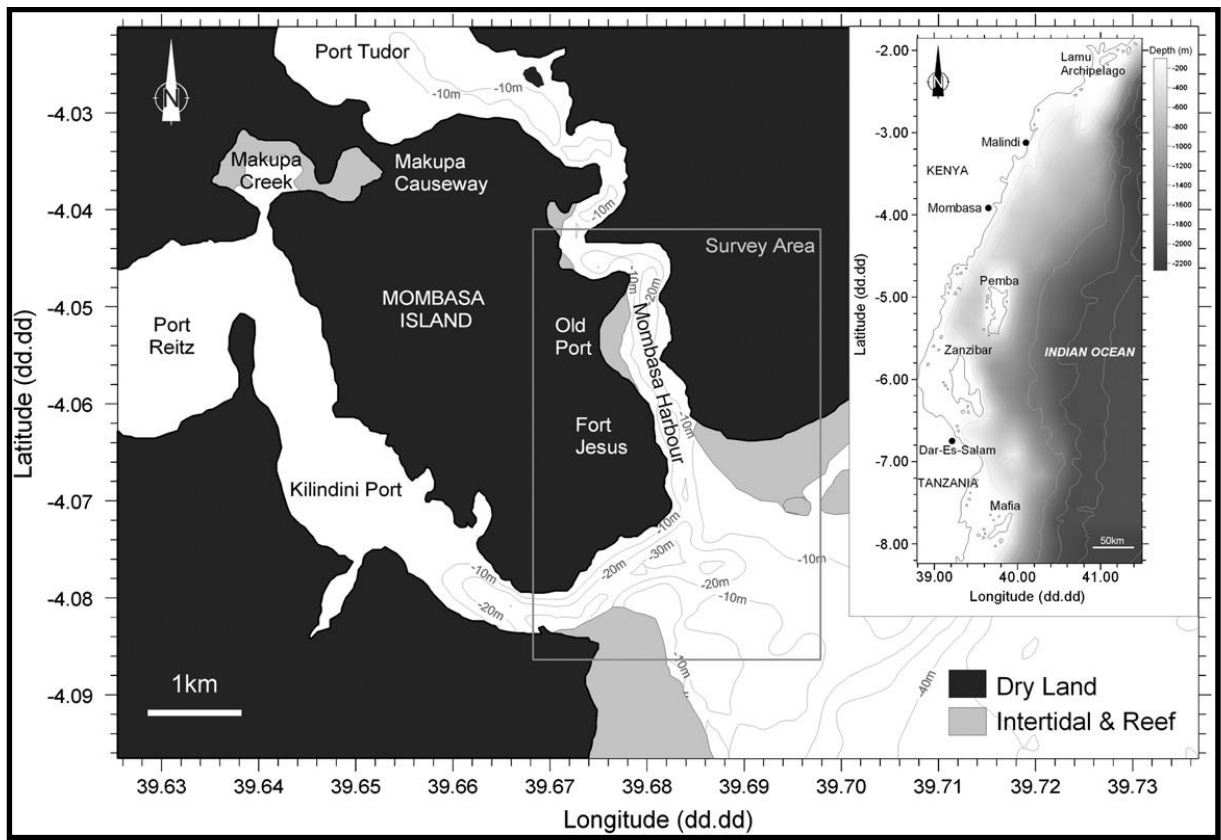

Fig 2. Map of Mombasa Island showing the old harbours (Rory, et al, 2007). 
The coastline is dominated by low coral cliffs, up to $20 \mathrm{~m}$ in height, serrated by small inlets, bays and promontories. The foreshore is largely composed of narrow coral platforms and some sandy beaches at the heads of the creeks. In spite of modern development, tropical vegetation, including mangroves, has survived in places on the coastal edge and foreshore (Rosemary and Thomas, 2007). Soils are generally thin, in many places underlain by shallow coral bedrock. The interior of the island is predominantly flat, with few natural landmarks. At the northwestern side a shallow ford at low water connects the island with the mainland in the past; more recently this has been made into a wide causeway, which together with Nyali Bridge at the southeast connects the island to the north and west mainland. These are the only land-based access routes between Mombasa and the mainland.

\section{Climate}

Mombasa has a warm, dry tropical monsoon climate with a less distinct rainy period. Temperatures are around $30^{\circ}$ Celsius on average; during the warmest days an ever blowing sea breeze offers some cooling. The amount of rainfall depends essentially on season. The rainiest months are April and May, while in January to February the rainfall is minimal (Rosemary and Thomas, 2007). Being on the coastal region, the climate is largely influenced by wind movements from the Indian Ocean. These include Northeast and Southeast Monsoons that are responsible for the rainfall patterns of this region. The Northeast Trade Winds are particularly associated with November to March short rains while the Southeast Trade Winds cause the long rain season, "Masika" which starts in April and ends in early June.

The climatic seasons are governed by these winds and correspond to the hot north-east also known as "Kaskazi" and cool south-east or "Kusi" monsoon (Gerhardt, 1986; Frazier, 1993; Richmond, 1997; Bita, 2012). The climate is hot during the months of December to April although temperatures remain comparatively high all year round, with a minimum of $25^{\circ} \mathrm{C}$ and a maximum of $30^{\circ} \mathrm{C}$. From May to September, temperatures drop to an average of $23^{\circ} \mathrm{C}$ whereas July records the lowest (Ndiiri, 1992). Rainfall in Mombasa is recorded to between 1100 - $1400 \mathrm{~mm}$ per annum. The weather is controlled by the monsoonal air currents of the Indian Ocean, in combination with coastal hills and the dry hinterland westwards. The relative humidity is high throughout the year, but highest in the rainy season (Bita, 2012).

\section{History of Mombasa}

Although the exact founding date of the city is unknown, Mombasa Island, settled for almost 2000 years, played a central role in the development of the central seaboard of East Africa, emerging by the 16th century as a centre of sustained port dominance (Rory, et al, 2007). It must have been already a prosperous trading town in the 12th century, as the Arab geographer Al Idrisi mentions (Freeman-Grenville, 1975; Sutton, 1990). It was a historical trading centre, and it has been controlled by many countries because of its strategic location.

Before the Portuguese, Mombasa was referred as a very fair place with lofty stone houses. It had the harbour in the creek, well protected from winds and traded with outside worlds including Sofala, Zanzibar, far and Middle East. Mombasa has a history of rivalries trading community and is thus a maritime landscape with most sites near the shore deliberately positioned to exploit the maritime potential (Boxer and Azevendo, 1960). The Arab rulers of this city were always at feuds with those of Malindi, $120 \mathrm{~km}$ north before the Portuguese established their base in the Kenya coast (Martin, 1973).

Most of the early information on Mombasa comes from Portuguese chroniclers writing in the 16th century. The famous Moroccan scholar and traveller Ibn Battuta did visit Mombasa in 1331 on his travels on the eastern coast of Africa and made some mention of the city, although he only stayed one night. He noted that the people of Mombasa were Shãfi'i Muslims, "a religious people, trustworthy and righteous with their mosques expertly built of wood" (Boxer and Azevendo, 1960). Mombasa became the major port city of pre-colonial Kenya during the Portuguese rein and was used to trade with other 
African port cities, Persia, Arab traders, Yemen, India and China. 15th century Portuguese voyager Duarte Barbosa claimed, "Mombasa is a place of great traffic and has a good harbour in which there are always moored small craft of many kinds and also great ships, both of which are bound from Sofala and others which come from Cambay and Melinde and others which sail to the island of Zanzibar" (Boxer and Azevendo, 1960).

During the pre-modern period, Mombasa was an important centre for the trade in spices, gold, and ivory. Its trade links reached as far as India and China and oral historians today can still recall this period of local history. Throughout the early modern period, Mombasa was a key node in the complex and far reaching Indian Ocean trading networks, its key exports then were ivory, millet, sesamum and coconuts. In the pre-modern period, Mombasa was an important centre for the trade in spices, gold, and ivory (Boxer and Azevendo, 1960). In the late pre-colonial period (late 19th century), it was the metropolis of a plantation society, but ivory caravans remained a major source of economic prosperity.

In 1698 , the town came under the influence of the Sultanate of Oman, subordinate to the Omani rulers on the island of Unguja (Zanzibar), prompting regular local rebellions. The town returned to Portuguese rule in 1729, through captain-major Álvaro Caetano de Melo Castro and later to the Oman Arabs. In the 1824 to 1826, there was a British protectorate over Mombasa, before Omani rule was restored in 1826. In 1887, its administration was relinquished to the British East Africa Association, later the Imperial British East Africa Company (IBEAC) and soon became the capital of the British East Africa Protectorate (Boxer and Azevendo, 1960). Today Mombasa is the second largest city in Kenya. It is a regional cultural and economic hub, with a large port that serves East and Central Africa, an international airport and is an important regional tourism centre.

\section{Ancient Maritime Connections of the Swahili coast}

One of the characteristics of the East African Coast has been its accessibility. The sea has been a means of contact with the outside world. Over the last 2000 years, there has been an interpenetration of cultures to this coast through trade consequently assimilating the regiont into the international economic system. Accessibility from the land has made the East African coast historically an integral part of Africa. This allowed movement of goods from inland to the coast and onward to international markets. The coast has a trade advantage because the monsoon winds and oceanic currents are reliable and permit rapid, seasonal navigation, both along the coast of eastern Africa and across the Indian Ocean to western and southern Asia (Figure 3). The Swahili coast has thus been a culturally dynamic region for centuries. The Swahili culture indeed has its origins in the maritime oriented subsistence among African communities of this coast most of whom were Bantu speakers living in the eastern board.

The Periplus of the Erythaean Sea (this document was written as a guide to the ports and trade of Arabia, East Africa, India and the connecting route to China) discusses the east African coast in relation to the Middle East and the Mediterranean (Huntingford, 1980; Casson, 1989; Horton, 1990). This ancient document indicates that the western Indian Ocean or Swahili coast was known very early in time. The document refers to a promontory (towards which the ocean current runs) which is likely to refer to the eastern tip of Somali coast or the Swahili coast (Chami, 1994; 1999; 2009). It further refers to the island of Menouthesias with many rivers, and many small sewn boats and dug-outs canoes. Down this Island (2 days) was the ancient city of Rhapta, whose name was derived from the small sewn boats. The town was said to have plenty of ivory and tortoise shell. Periplus adds that the people of Mouza used to send there small boats with Arab captains and crew to trade and intermarry with the mainlanders and learn their languages (Freeman-Grenville, 1962; Sheriff, 2000; 2002). This document gives impression that at the port of Rhapta in the East African coast, trade was exercised by Arab captains. The most important economic function was export of great quantities of ivory, rhinocerous horns, high quality tortoise shells exchanged for lances, hatches, daggers, awls, glass. Ptolemy adds that this trade was growing rapidly in the early centuries of $\mathrm{AD}$ (Mathew, 1963; Sheriff, 2002). Based on ancient records 
by Graeco-Romans, Arabs and Chinese travelers, archaeological research in the Swahili coast has shown existence of cities as mentioned in these early records. Such include Lamu, Malindi, Mombasa and Rhapta most of which were trading centres (Chami, 1994; 2006).

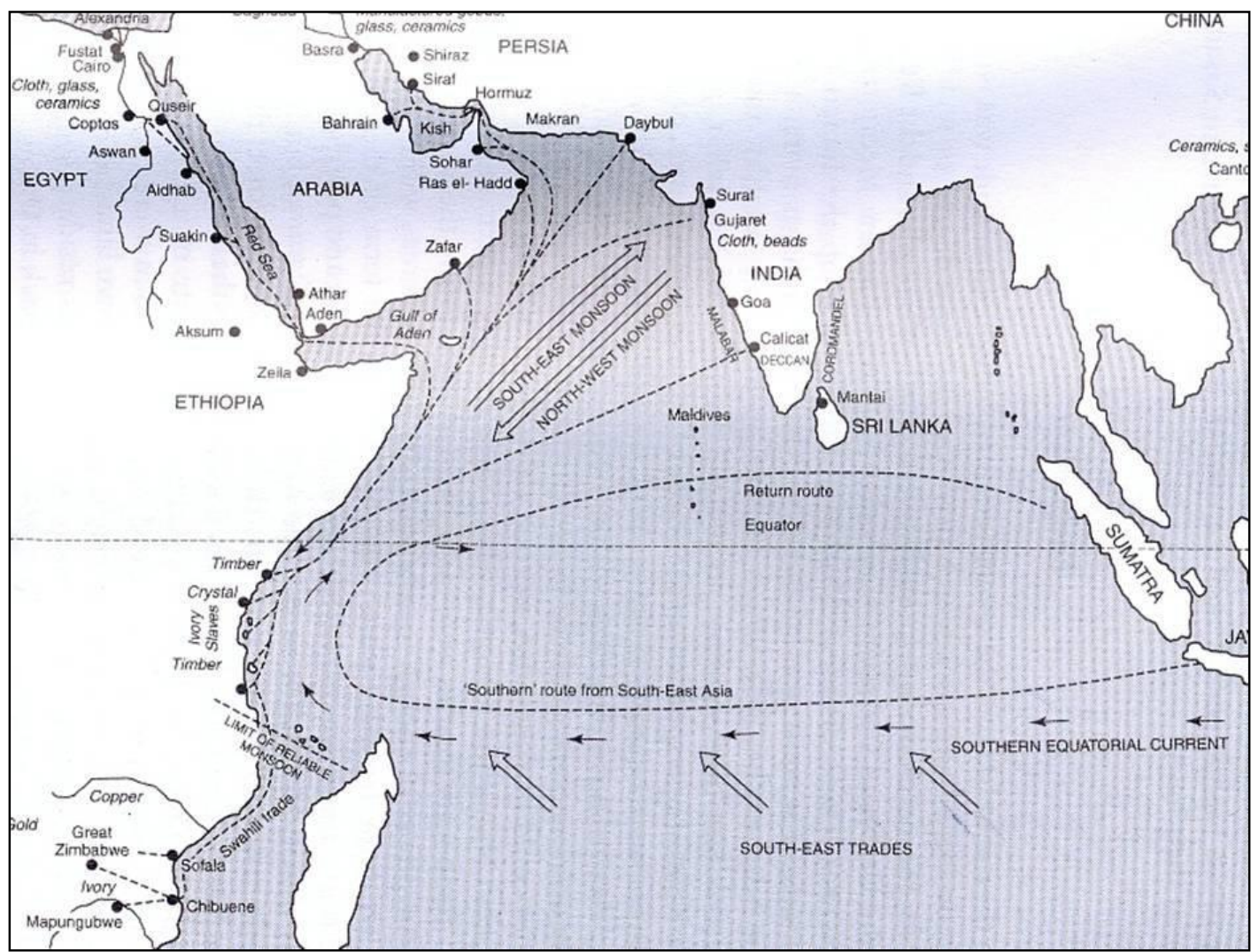

Fig 3. Monsoon winds that enabled ancient network of sailing routes to the East African coast (Chami, 2006).

Contrary to common assertion, there was massive commercial intercourse between WIO and India, Middle East before the 7th century (Hourani, 1963; Whitehouse, 2001). For instance, India, though seemed to be self supportive in wood products that East Africa could have produced, India indeed was an active exporter of ivory at this time and later importer of East African ivory (Sheriff, 2002). Exploitation however came after death of Alexander; and the Ptolemies wished to break Seleucid monopoly over supply of Indian ivory to the Mediterranean and therefore turned to the East African coast. A growing demand in Italy for Indian products when resources were depleting forced the Egyptian to look south to East African coast for ivory. It may be difficult to determine exactly how early and down the East Africa trade connections extended before the present era without archaeological evidence (Freeman-Grenville, 1975; Sheriff, 2000; Chami, 2009).

East Africa thus formed a vital link in the Western Indian Ocean trade between East Asia and the northern coast of Somalia including Egypt and the hinterland. The Arabs apart from exporting frankincense and myrrh were largely the intermediaries in the WIO trade between Indian and Mediterranean and seemed to enjoy the monopoly over the trade with the East Africa coast. This and the unification and increased opulence of the Roman Empire led to a fresh stimulus of the WIO maritime trade. When demand for ivory increased within the Roman Empire, East African ivory became to be used, though at first thought to be of lower quality further integrating and showing how the East 
African coast played its role in the international maritime trade across the Indian Ocean (Chami, 1994; 2006; Sheriff, 2002).

After collapse of Rome, Persians continued to dominate the Indian Ocean trade for a considerable period thereafter, bequeathing a significant nautical and commercial vocabulary to the whole of Indian Ocean world. They became intermediary of East Africa and India. Their command of the Indian Ocean in the 6th and 7th Century AD suggests that they had a dominant commercial influence over East African coast. The traditions of Shiraz (Persian) migration to the East Africa coast may have begun originate during this period. The collapse deprived East Africa of market of its ivory while by beginning of 6th century demand for ivory in India was raising. By the 10th century, India and China were the most important markets of ivory from East Africa (Mathew, 1963).

\section{Evidence of Ancient Greek and Phoenicians contact with East African Coast}

The Swahili coast was visited by foreigners very early in time. Ancient accounts by travelers have reported this coast was inhabited by Africans from ancient times (Freeman-Grenville, 1975). For example the, Graeco-Roman sources of the 1 st and 2 nd centuries A.D allude to early African settlements along the Kenyan and Tanzanian coasts (Hollingsworth, 1951; Datoo, 1970; Freeman-Grenville, 1975; Huntingford, 1980; Wright, 1984; Kirwan, 1986; Casson, 1989; Horton, 1984; 1987; 1990; Chami, 1994; 2006). The anonymous Periplus of the Erythrean Sea (A.D. 40 - 70) and Ptolemy's Geography (A.D. 140) mention routes, ports and goods in the East African coast involved in trade with the Red Sea, Mediterranean and the rest of the Indian Ocean (Freeman-Grenville, 1975; Chami, 1994; D'Souza, 2008). They refer to the Swahili settlements as inhabitants who traded ivory and tortoise shell in exchange for metal objects (Stigand, 1913; Casson, 1989; Horton, 1990). Similarly they mention the towns as each ruled by its chief and the inhabitants using sewn boats (Freeman-Grenville, 1975). Later Arab, Chinese and Portuguese visitors also visited and described this coast (Freeman-Grenville, 1975). Portuguese documents and chronicles show that for centuries, the eastern Africa coast had developed trade links with the Arab world (Boxer, 1960; Freeman-Grenville, 1975; Sutton, 1990).

These historical records have also shown that the East African coast was connected to ancient global trade networks. These early overseas contacts are evidenced by references to trading voyages in the early 1 st millennium $\mathrm{AD}$ and in the 11th to 14 th century AD. During these periods, exports to India, China and the Persian Gulf included skins, horns, ivory and gold, whilst pottery, glass, textiles and beads were imported. Maritime archaeological studies have produced pottery, beads and shipwrecks that have showed links between East Africa and the Middle East, Indian sub-continent and China (Piercy, 1977; 1978; Sassoon, 1980; Patience, 2006; Rosemary and Thomas, 2007; Bita, 2008; 2009a; 2009b; 2011b). Furthermore, historic Kenyan coastal settlements such as Mombasa, Malindi and Lamu were important port towns of call for merchant shipping, as they were strategically sited along busy sea-lanes. Studies in this coast show that early Swahili settlements ranging in time from the 8 th -17 th centuries are found along the entire coast in close proximity of the ocean. Other sites were on offshore islands but often so close to the mainland as to be virtually part of it like Mombasa, Lamu, Pate and Siyu (Garlake, 1966; Chittick, 1984; Horton, 1984; Abungu, 1989).

Archaeological works on the coast of Kenya have revealed that the coastal belt of Kenya has been settled since the Pleistocene, through the early pre-Islamic and Islamic periods to the present (Kusimba, 1999). Throughout the periods, communities who settled along the coast established themselves as fishermen, farmers or traders. The fishermen learnt the art of fishing, construction of boats and sailing. At the same time the Kenyan coast, being part of the Western Indian Ocean was visited by seafarers from China, Persia, and Greece as early as 2000 BC (Hourani, 1963). Those who visited the coast left evidence in form of ceramics, architectural designs, and socio-linguistic traces and in form of shipwrecks that are reported in the seabed of Kenya. These suggest therefore that the western Indian Ocean was connected from very early probably as far as the Harappa Civilization $(2600-1760 \mathrm{BC})$. 
Excavations have recovered evidence in the form of Ptolemic gold coins of late 2nd century BC and 4th century AD (Chami, 1994; 2009). Further archaeological excavations in this coast have continued to unearth high quantities of sgraffiato, Chinese ceramics, Sassanid ware, beads and glass. Studies in Zanzibar have yielded Indian and Graeco-Roman beads including carnelian bead and red, blue and green glass bead all dating 1st millennium BC (Chami, 1999; 2009). The ancient Indian trade wind beads 'Mutisalah' beads according to Dubin (1987) seem to have arrived in East Africa several centuries before BC/AD changeover. This type of bead was widespread in South East and Far East Asia from about $300 \mathrm{BC}$ or earlier. There is no doubt that this same bead was traded in East African coast during the same period (Chami, 2009). Further, the abundance of Sassanian pottery in many archaeological sites from southern Somali to Comoro and Mozambique indicate ancient contacts existed between Swahili coast and Persia under the sassanid rule (Chami, 1994; 2006; Whitehouse and Williamson, 1973).

Other evidence comes in the form of references. For instance there are references to Egyptians having circumvented the Africa continent while both Egyptian and early Roman literature mention trade with East Africa involving items such as animal products (skins and horns) metal and spices (Chami, 1994; 1999; 2006; 2009; Sheriff, 2000). Spices and cinnamon came from Asia suggesting the Swahili coast was the meeting point (Chami, 2009). There is no question that the beginning of the Kiswahili language can be traced to this historical maritime trade that led to a convergence of ethnic groups to create a trading language (Masamba, 2007). Egyptians records suggested that two routes used to reach Punt (East African coast): One along the Nile valley and the other through the Red Sea. There are also references to the importing of slaves from the Swahili coast as soldiers, domestics and agricultural labourers to reclaim the marshlands of southern Iraq. By end of 7 th $\mathrm{C}$ these slaves were numerous enough as to stage a revolt in Baghdad. There are also reports of Zanj slaves reaching China as early as 7th century AD (Stigand, 1913; Mathew, 1963; Sheriff, 2002).

\section{Historical Period Stone Anchors From Mombasa}

Underwater archaeological surveys have also recovered artifacts that suggest early contacts between the Swahili coast and the Phoenicians and Greeks. These have come in the form of stone anchors, some recovered from the sea near Mombasa. Such types of anchors are a common occurrence in the western coast of India around Goa (Tripati and Sundaresh, 1998; 2003; 2006; Tripati and Patnaik, 2008), and the ancient Mediterranean region.

\section{The Survey}

There have been numerous underwater archaeological surveys of Mombasa Island in the previous years that realized a lot of maritime and underwater archaeological sites (Breen and lane, 2003; Patience, 2006; Rory et al, 2007; Bita, 2008; 2009b, 2011b). The first such survey was undertaken for the Portuguese Santa Antonio shipwreck which recovered Indian wares, Chinese porcelain, Martaban and Portuguese jars, canons, mortar shells and bronze artifact (Piercy, 1977; 1978; Sassoon, 1980). Much of this wreck lies gazetted and preserved in situ, while recovered artifacts are in conservation and exhibition at the Fort Jesus Museum, Mombasa. Following this survey, subsequent studies have been undertaken of Mombasa in which a lot of archaeological materials have been documented. These include a 2001 collaborative maritime archaeological study of Mombasa Island by National Museums of Kenya in collaboration with the British Institute in Eastern Africa and Ulster University (Breen and Lane 2003). Others are the shipwreck and salvage studies by Patience (2006) and maritime and underwater archaeological surveys by Bita (2008; 2009b; 2011b).

In 2008, National Museums of Kenya undertook maritime survey of Mombasa channel focusing on the Tudor Channel in front of Fort Jesus Monument and at the entry to the old port of Mombasa (see Map 2). The survey mainly involved systematically walking and recording of archaeological remains on the intertidal and foreshore zone as well as underwater dive and geophysical surveys. The aim of the underwater survey was to determine the probable line for a fibre optic cable to be laid in the sea bottom. A corridor of $20 \mathrm{~m}$ was created for surveying starting in front of Mombasa club and extending to the open waters (Map 2). 


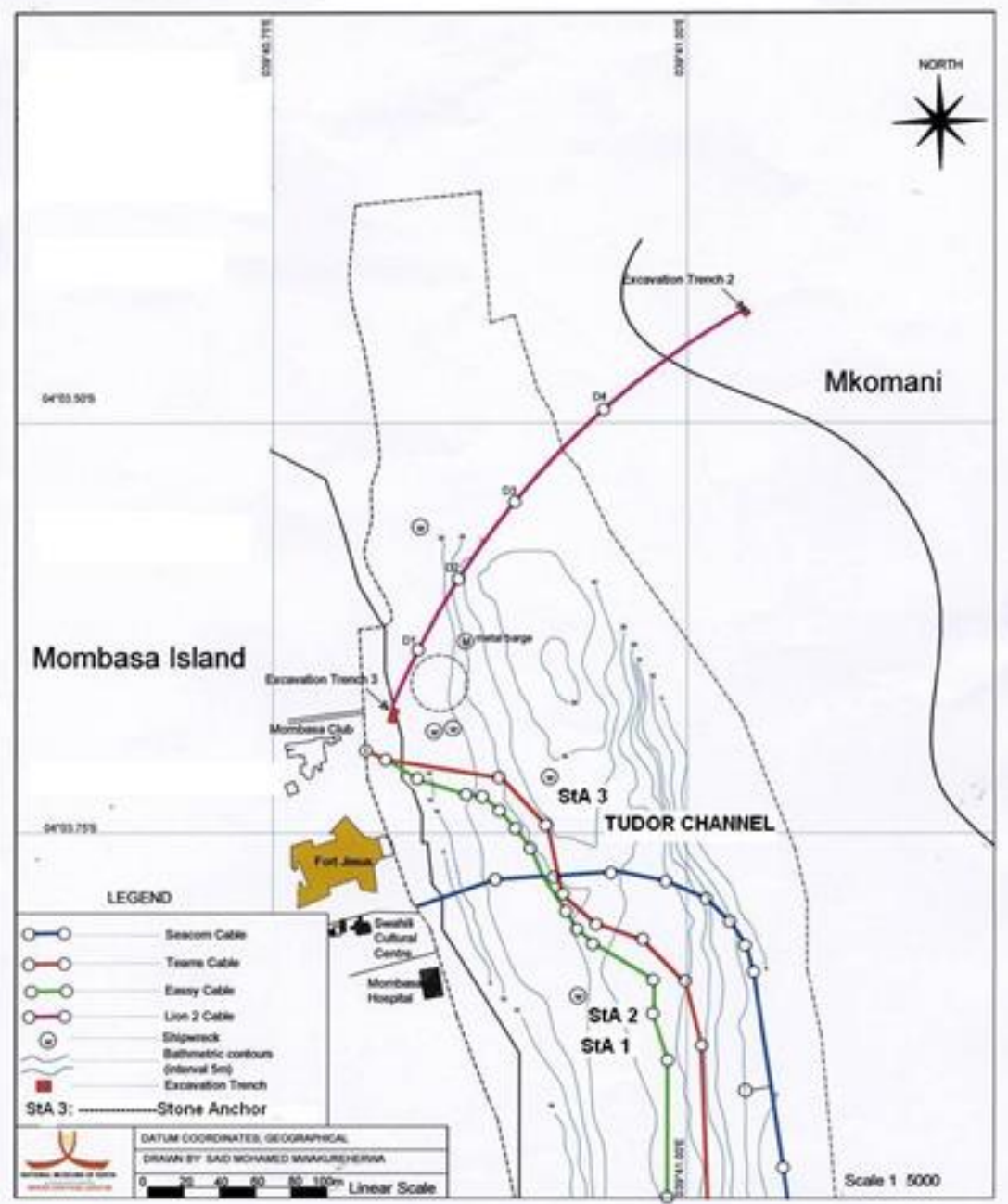

Map 1. Survey Map of Tudor Channel showing location stone anchors were found (Bita, 2011b).

Scanning of the seabed was done using a number of equipment: The side-scan sonar collecting data on all anomalies, the sub-bottom profiler and single beam depth sounders. Later dive surveys were undertaken during which several shipwreck sites were recorded.

However, during the same period local divers discovered, some $100 \mathrm{~m}$ from the surveyed area, two stone anchors with triangular and cuboidal profiles. Some of the finds did not have detailed information such as exact date of recovery (Bita, 2008). This prompted further survey of the area in which one more stone anchor (Plates $1-3$; Figure 4; Table 1) was retrieved (Bita, 2009b; 2011b). On going underwater archaeological surveys have established these anchors are a common occurrence in the coast around Mombasa Island. 

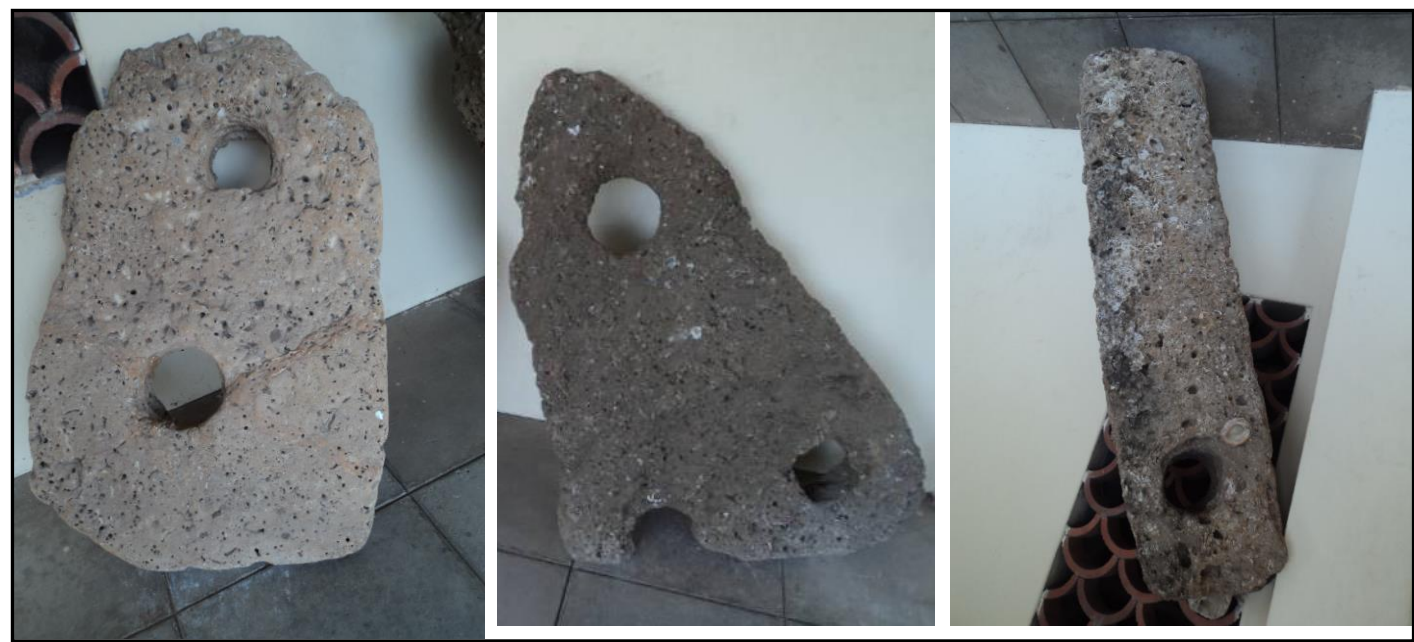

Plate 1-3. Ancient Stone anchors from Mombasa on display at the Fort Jesus Museum, Mombasa, Kenya (Courtesy: Fort Jesus Museum, Mombasa)

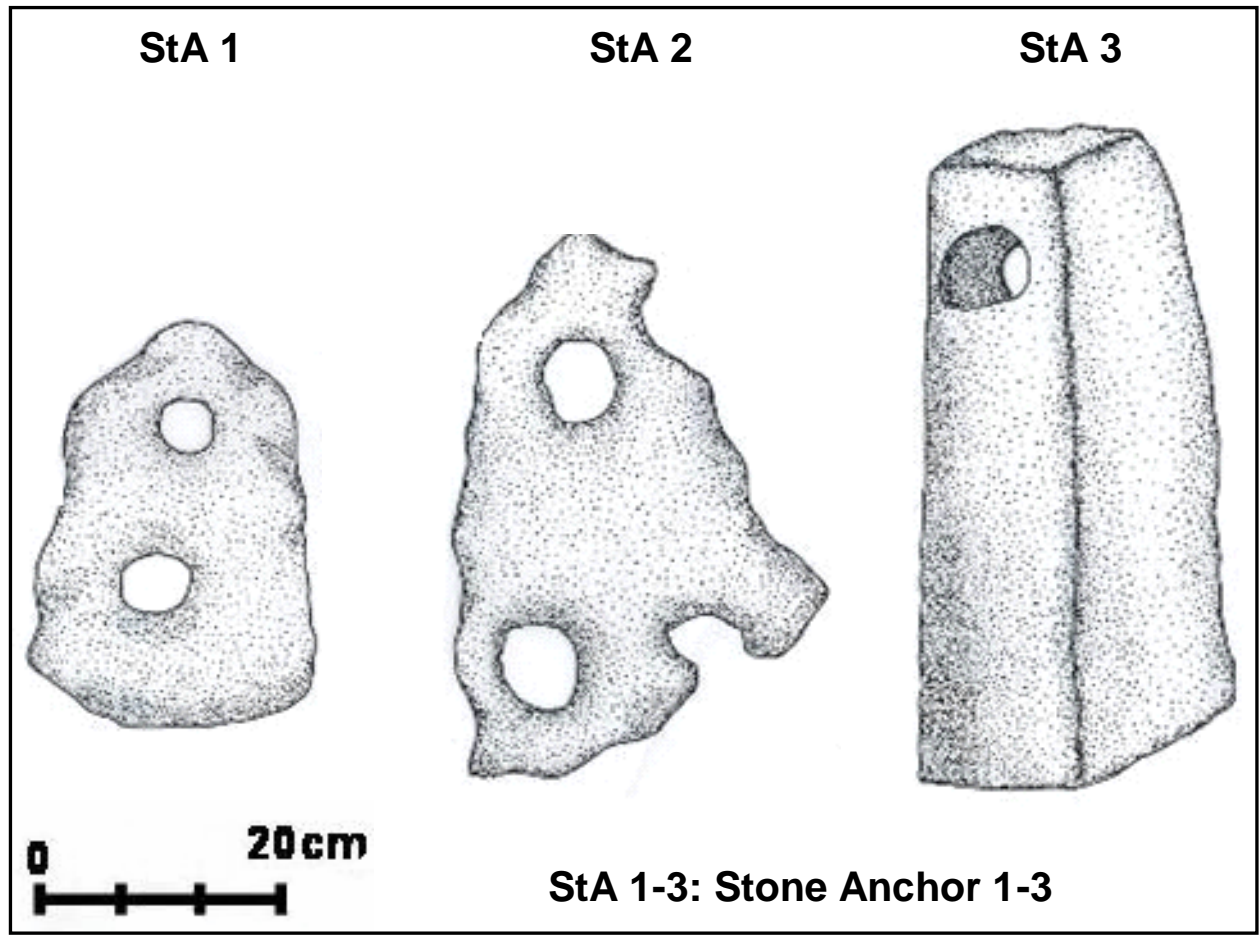

Fig 4. The three Stone Anchors recovered from Mombasa, Kenya.

Table 1. Dimensions of stone anchors found in Mombasa waters, (all in $\mathrm{cm}$ ).

\begin{tabular}{|c|l|c|c|c|c|c|c|c|c|}
\hline S/No & Location & Material & Width $(\mathbf{c m})$ & $\begin{array}{c}\text { Length } \\
(\mathbf{C m})\end{array}$ & $\begin{array}{c}\text { Lower } \\
\text { Holes }\end{array}$ & $\begin{array}{c}\text { Upper } \\
\text { Holes }\end{array}$ & State & $\begin{array}{c}\text { Weight } \\
(\mathbf{K g s})\end{array}$ & Shape \\
\hline 1 & Mombasa & Coral & $\begin{array}{c}\text { Top }: 50 \\
\text { Bottom:63 }\end{array}$ & $95 \mathrm{~cm}$ & 16 & 13 & Good & - & Rectangle \\
\hline 2 & Mombasa & Coral & $112 \times 134 \times 90$ & - & $19 \times 17$ & $17 \times 13$ & Good & - & Triangle \\
\hline 3 & Mombasa & Coral & $\begin{array}{c}\text { Top: } 20 \times 30 \\
\text { Bottom:33 } 37\end{array}$ & 148 & - & $16 \times 18$ & Good & & Rectangle \\
\hline
\end{tabular}




\section{Acknowledgements}

I thank the Director General, National Museums of Kenya, for his support. I am also grateful to the British Institute in Eastern Africa and University of Ulster for the collaborative survey of Mombasa, UNESCO for sponsorship to Underwater Cultural Heritage training courses. Thanks too to the Chinese government for the bilateral cooperation in underwater archaeology research in Kenya. The cooperation given by SEACOM, EASSY, TEAMS, TELKOM (K) Limited and Kenya Ports Authority during Underwater Cultural Heritage Impact Assessments of Mombasa is highly appreciated.

\section{References}

Abungu, G. O 1989. Communities on the river Tana, Kenya: An Archaeological study of relations between the Delta and the river basin, 700 - 1800 A.D, Ph.D. Thesis, University of Cambridge.

Ase, L. E., 1987. "Sea-level changes on the east coast of Africa during the Holocene and late Pleistocene", in Tooley, M. and Sherman, I (eds.), Sea-level changes, Oxford, Blackwell, pp 276 - 295.

Ase, L. E., 1981. "Studies of shores and shore displacement on the southern coast of Kenya - especially in Kilifi District", Geografisker Annaler, 63A: 303 - 310.

Bita, C., 2012. The Origin of Malindi Town. A Case Study of Mambrui, M.A. Dissertation. University of Dar es Salaam. Dar es Salaam.

Bita, C., 2011a. Ancient Afro-Asia links. New evidence from a maritime perspective. Proceedings on the Asia-Pacific Regional Conference on Underwater Cultural Heritage, November 8-12, 2011. Manila, Philippines.

Bita, C., 2011b. Cultural Heritage Impact Assessment for the Lion 2 Undersea Fibre
Optic Cable in Mombasa. National Museums of Kenya. Mombasa.

Bita, C., 2009a. Inter-tidal and foreshore survey of Pate island, Survey report, Fort Jesus Museum. Mombasa.

Bita, C., 2009b. The intertidal and foreshore archaeology of Mombasa Island: An inventory of maritime sites, Survey report, Fort Jesus museum, Mombasa.

Bita, C., 2008. Maritime archaeological survey of Mombasa channel. Inter-tidal and seabed survey. Cultural Heritage Impact Assessment report, Fort Jesus museum, Mombasa.

Boxer, C. R., and de Azevedo, C., 1960. Fort Jesus and the Portuguese in Mombasa, 1593 - 1729, Hollis and Carter, London.

Boxer, C., 1960. Fort Jesus and Portuguese in Mombasa, London, British Museum.

Breen, C., and Lane, J. P., 2003. "Archaeological Approaches to East Africa's Changing Seascapes", World Archaeology, Taylor and Francis Ltd, 35: (3) $469-489$.

Casson, L., 1989. Periplus Maris Erythreai. Text with introduction, translation and commentary, Princeton University Press, Princeton.

Chami, F, 2009. Zanzibar and the Swahili Coast from c.30 000 years ago, E \& D Vision Publishing, Dar es Salaam.

Chami, F., 2006. The Unity of African Ancient History: $3000 \mathrm{BC}$ to $\mathrm{AD} 500, \mathrm{E}$ and D Publishers, Dar es Salaam.

Chami, F., 1999. Roman beads from the Rufiji Delta, Tanzania: first incontrovertible Archaeological link with Periplus, in Current Anthropology, 40: 237-241.

Chami, F.,1994. The Tanzanian Coast in the First Millennium A.D: An Archaeology of the iron Working, Farming Communities, Uppsala, Societas Archaeological Uppsaliensis. 
Chittick, H. N., 1984. Manda. Excavations at an island port on the Kenya coast, Nairobi, British Institute in Eastern Africa, memoir 9.

Datoo, B. A., 1970. "Rhapta: The location and importance of East Africa's first port", Azania, 5: 65 - 77.

Dubin, I., 1987. The history of beads from $30,000 \mathrm{BC}$ to the present. London.

Thames and Hudson D'Souza, B. R., 2008. Harnessing the trade winds. Story of the centuries old trade with East Africa using the monsoon winds, Zand Graphics, Nairobi.

Freeman-Grenville, G. P., 1975. The East African Coast: Selected documents from the first to earliest nineteenth century, Oxford, Clarendon Press.

Freeman-Grenville, G. P., 1962. The medieval history of the coast of Tanganyika, London, Oxford University Press.

Frazier, J. G., 1993. "Dry coastal ecosystems of Kenya and Tanzania" in Maarel, E.V.D. (ed.), Ecosystems of the world: Africa, America, Asia and Oceania, (Vol. 2B), Hamburg, LIT Verlag, pp. 249 - 260.

Garlake P. S., 1966. The early Islamic architecture of the east African coast, Nairobi, Oxford University press.

Gerhardt, K. S., 1986. An inventory of a coastal forest in Kenya: Gedi National Monument and Nature trail, Swedish University of Agricultural Sciences, International Rural Development, Uppsala.

Hollingsworth, L., 1951. A Short History of the East Coast of Africa, London, Macmillan.

Horton, M. C., 1990. The Periplus and East Africa, in Azania, 25: 95-99.

Horton, M. C., 1987. Early Muslim trading settlements on the East African Coast: New Evidence from Shanga, in Antiquaries Journal, 67: 290-322.

Hourani, F. G., 1963. Arab Seafaring, Khayats, Beirut.

Huntingford, G. W., 1980. The Periplus of the Erythraean Sea, London, Hakluyt Society.
Horton, M. C., 1984. The early settlement of the northern Swahili coast, Ph.D. Thesis, University of Cambridge, Cambridge.

Kirwan, L. P., 1986. "Rhapta: Metropolis of Africa", Azania, 21: 99 - 114.

Kusimba, C. M., 1999. The Rise and fall of Swahili States, London, Altmara Press.

Martin, E. B., 1973. A history of Malindi, Nairobi, East African Literature Bureau.

Masamba, D., 2007. Kiswahili Origins and the Bantu divergence - convergence theory. Institute of Swahili research. University of Dar es Salaam.

Matthew, G., 1963. The East African Coast until the coming of the Portuguese, in History of East Africa, R. Oliver, and G. Matthew, Eds. Clarendon Press, Oxford, 94-28.

Ndiiri, W., 1992. An Ethno-archaeological Study of Contemporary Local Pottery on the Kenyan Coast, M.A. Thesis, Kenyatta University, Nairobi.

Patience, K., 2006. Shipwrecks and Salvage on the East African Coast, Dar Akhbar Al Khaleej, Bahrain.

Piercy, R, C, M., 1978. "Mombasa wreck excavation, preliminary report," International Journal of Nautical Archaeology, 7: 301 - 19.

Piercy, R, C, M., 1977. "Mombasa wreck excavation, preliminary report," InternationalJournal of Nautical Archaeology, 6: 331 - 47.

Richmond, M. D., 1997. A field guide to the seashores of eastern Africa and the Western Indian Ocean Islands, Sida / Sarec, Eurolitho, Milano.

Rory, Q., Wes F., Colin, B.,Donal, B.,, Paul, L., Athman, L., 2007. Process-based models for Port evolution and wreck site formation at Mombasa, Kenya Journal of Archaeological Science 34: 1449 -1460

Rosemary M., and Thomas M., 2007. Mombasa Island: A Maritime Perspective. International Journal of Historical Archaeology, Vol. 11, No. 2, Springer Science + Business Media, LLC 
Sassoon, H., 1980. Mombasa Wreck Excavation. Interim Report National Museums of Kenya, Nairobi.

Sheriff, A., 2002. Slaves, Spices and Ivory in Zanzibar. Oxford. James Carrey

Sheriff, A., 2000. Coastal Interactions. Journal of African History 43: 317-318

Sutton, J. E., 1990. A thousand years of East Africa, British Institute in East Africa, Nairobi.

Stigand, C., 1913. The Land of Zinj, London.

Tripati, S., Sundaresh, A.S., and Gaur, 2006. Exploration of a Portuguese shipwreck in Goa Waters, western coast of India, in Bulletin of the Australasian Institute for Maritime Archaeology 30: 127-136.

Tripati, S., Gaur A. S., and Sundaresh, 2003. Anchors from Goa waters, Central West Coast of India: Remains of Goa's overseas trade contacts with Arabian countries and Portugal. Bulletin of the Australasian
Institute for Maritime Archaeology, 27: 97-106

Tripati, S., Gaur A. S. and Sundaresh, 1998. Historical period stone anchors from Vijaydurg on the west coast of India. Bulletin of the Australasian Institute for Maritime Archaeology 22:1-8.

Tripati, S., and Patnaik A. P., 2008. Current Science, Vol. 94, No. 3

Whitehouse, D., 2001. "East Africa and the maritime trade of the Indian Ocean A.D. 800 - 1500", in Amenoreti, B.S (ed.), Islam in East Africa: New Sources, Rome, Herder, pp $411-424$.

Whitehouse, D., and Williamson, A., 1973. Sasanian Maritime trade” Iran, II: 29 - 49

Wright, H. T., 1984. "Early seafarers of the Comoro Islands: the Dembeni phase of the IXth - Xth centuries A.D.", Azania, 19: 13 -60 . 